\title{
PEMEROLEHAN BAHASA PERTAMA PADA ANAK ADHD DI SEKOLAH ALAM JABALUSSALAM BALIKPAPAN
}

\author{
Nova $^{1}$, Indah Ika Ratnawati ${ }^{2}$, Maryatin ${ }^{3}$ \\ Universitas Balikpapan ${ }^{1}$, Universitas Balikpapan ${ }^{2}$, Universitas Balikpapan ${ }^{3}$ \\ Pos-el: novariantiaulia@gmail.com¹, indah.ika@uniba-bpn.ac.id², maryatin@uniba-bpn.ac.id ${ }^{3}$
}

\begin{abstract}
ABSTRAK
Penelitian ini dilatarbelakangi oleh kemampuan berbahasa anak ADHD yang mengalami keterlambatan bicara. Penelitian ini bertujuan mendeskripsikan tentang pemerolehan bahasa dan kesalahan fonologi pada anak ADHD yang mengalami keterlambatan bicara di Sekolah Alam Jabalussalam Balikpapan. Pemerolehan bahasa berupa berupa pemerolehan fonologi dan sintaksis. Untuk kesalahan fonologi berupa kesalahan pelafalan fonem konsonan. Penelitian ini merupakan penelitian kualitatif, data penelitian ini adalah ujaran dan percakapan. Subjek penelitian ini adalah seorang anak laki-laki berusia 7 tahun yang memiliki gangguan perkembangan yang disebut ADHD. Objek penelitian ini adalah pemerolehan bahasa dan kesalahan fonologi. Teknik pengumpulan data yang dilakukan dalam penelitian ini dilakukan menggunakan metode simak libat cakap (SLC) dan rekam. Instrumen penelitian ini berupa peneliti sendiri (human instrument) beserta alat bantu rekam berupa handphone dan kartu data. Data yang diperoleh selanjutnya dianalisis secara deskriptif. Hasil penelitian menunjukan bahwa pemerolehan fonologi pada anak ADHD antara lain fonem konsonan /b/, /c/, /d/, /f/, /g/, /h/, /j/, $/ \mathrm{k} /, / \mathrm{l} /, / \mathrm{m} /, / \mathrm{n} /, / \mathrm{p} /, / \mathrm{r} /, / \mathrm{s} /, / \mathrm{t} /, / \mathrm{w} /, / \mathrm{y} /, / \mathrm{z} /$ dan pemerolehan sintaksis antara lain frasa nominal, frasa verbal, frasa depan, frasa bilangan serta kalimat berita dan kalimat suruh. Kemudian untuk hasil penelitian kesalahan fonologi antara terjadi perubahan fonem penghilangan fonem konsonan dan penambahan fonem konsonan $/ \mathrm{h} /$.
\end{abstract}

Kata Kunci: Pemerolehan Bahasa, Anak Adhd, Sekolah Alam.

\begin{abstract}
This research is motivated by the language skills of ADHD children who experience speech delay. This study aims to describe language acquisition and phonological errors in ADHD children who experience speech delay at Jabalussalam Balikpapan Nature School. Language acquisition is in the form of phonological and syntactic acquisition. For phonological errors in the form of errors in pronunciation of consonant phonemes. This research is a qualitative research, the data of this research are speech and conversation. The subject of this study was a 7-year-old boy who had a developmental disorder called ADHD. The object of this research is language acquisition and phonological errors. Data collection techniques carried out in this study were carried out using the capable involvement (SLC) method and recording. This research instrument is in the form of the researcher himself (human instrument) along with recording tools in the form of cellphones and data cards. The data obtained are then analyzed descriptively. The results showed that phonology acquisition in ADHD children included

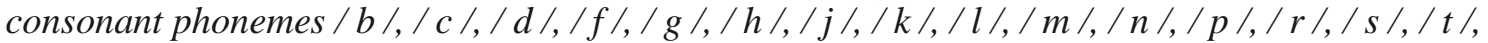
$/ w /, / y /, / z /$ and syntax gains include nominal phrases, verbal phrases, front phrases, number phrases as well as news sentences and sentences. Then for the results of research phonological errors between phoneme changes in consonant phoneme removal and the addition of consonant phonemes / $h /$.
\end{abstract}

Keywords: First Language Acquisition, Children With ADHD, Nature School. 


\section{PENDAHULUAN}

Salah satu cara berinteraksi dengan orang lain tentunya melalui proses komunikasi. Komunikasi merupakan hal yang mendasar dalam menjalani kehidupan sehari-hari. Manusia selalu menyampaikan apa yang mereka rasakan dan butuhkan dengan berkomunikasi dengan orang lain. Adapun alat komunikasi antar sesama manusia adalah bahasa. Seorang bayi sejak dilahirkan sudah mampu mengungkapkan bahasanya secara sederhana yakni melalui tangisan. Kemudian seorang bayi yang semula hanya dapat berbahasa melalui tangisan ketika usianya bertambah maka ia akan mampu mengungkapkan bahasanya secara verbal maupun nonverbal. Perkembangan setiap anak tentunya berbeda-beda. Tergantung stimulus yang mempengaruhi si anak sejak dalam kandungan. Salah satu gangguan perkembangan anak adalah Attention Deficit Hyperactivity Disorder atau disingkat menjadi ADHD, dalam bahasa Indonesia disebut Gangguan Pemusatan Perhatian dan Hiperaktivitas. Paternotte (2010, p. 1) menyatakan bahwa ADHD adalah suatu gangguan neuro-biologis di dalam otak yang dapat secara parah mengancam tumbuh kembang seorang anak. Pada umumnya di usia 5 sampai 7 tahun, seorang anak sudah mampu mengucapkan kalimat dengan baik. Berdasarkan hasil rekam medis MR dari klinik Harapanku, MR memiliki gangguan perkembangan (ADHD) dalam keterlambatan bicara (speech delay) atau biasa disebut dengan gangguan bahasa dan bicara. Sehingga MR belum mampu mengucapkan ujaran dengan baik dan benar.

\section{METODE PENELITIAN}

Dalam penelitian ini, peneliti mengunakan pendekatan psikolinguistik. Penelitian ini menggunakan penelitian jenis kualitatif. Sumber data primer pada penelitian ini adalah siswa berinisial MR, berjenis kelamin laki-laki dengan dengan ADHD. MR bersekolah di Sekolah Alam Jabalussalam Balikpapan. Dalam penelitian ini peneliti menggunakan metode simak libat cakap, sadap dan catat. Instrumen pendukung pada penelitian ini adalah alat perekam suara (handphone), laptop, alat tulis berupa buku dan pulpen, dan kartu data. Keabsahan data Peneliti menggunakan teknik ketekunan pengamatan. Peneliti membaca berulang ulang mengenai isi data penelitian ini. Pemeriksaan teman sejawat serta kecukupan bahan referensial.

\section{HASIL DAN PEMBAHASAN}

1.Pemerolehan Fonologi

Konsonan hambat letup apiko-dental Pemerolehan fonologi pada MR pada jenis fonem konsonan hambat apikodental sebagai berikut.

\begin{tabular}{|l|l|l|}
\hline Tegah & Towong & Tapi \\
\hline Tida & Tayik & \\
\hline
\end{tabular}

Konsonan hambat letup apiko-dental adalah konsonan yang terjadi bila penghambat artikulator aktifnya adalah ujung lidah dan artikulator pasifnya adalah gigi atas. Bunyi yang dihasilkan adalah /t/, /d/. Bunyi dental /t/ adalah konsonan keras tidak bersuara, sedangkan /d/ adalah lunak bersuara dan hambatannya lebih pendek daripada /t/.

Fonem konsonan / $t /$ adalah fonem konsonan hambat letup apiko-dental keras tidak bersuara. Fonem konsonan hambat letup apiko-dental atau /t/ terdapat pada awal kata antara lain: Tegah, towong, tida, tayik, tapi. Untuk fonem konsonan hambat letup apikodental atau /d/ pada ujaran MR tidak ada.

\section{Perubahan Fonem Konsonan}

a. Perubahan fonem konsonan /f/ dilafalkan /p/

Kesalahan pelafalan fonologi karena perubahan pelafalan fonem konsonan ini disebabkan penutur tidak dapat 
melafalkan fonem konsonan pada kata yang seharusnya dilafalkan.

GR : Panggil Lutfinya, Lutfi siap ?

MR: Upi piap

(Data No. 1/PR/9/4/2018)

Ujaran: Upi piap

Arti: Lutfi siap

Pengujar: GR (Guru), MR (Subjek

Penelitian)

Konteks:GR meminta MR untuk memanggil temannya yang bernama

Lutfi. GR meminta MR untuk

mengatakan Lutfi siap, MR mengikuti

ujaran GR dengan kalimat Upi piap.

Dari kutipan di atas terdapat kataUyaran mengalami kesalahan pelafalan. AKtata yang mengalami kesalahan adalalPekajajar Upi. Kata Upi dalam bahasa indonesia tidak memiliki makna. Berdasarkan konteksnya untuk mengisi pelafalan yang sesuai adalah Lutfi. Dari uraian di atas terjadi kesalahan pelafalan fonem /f/ dilafalkan /p/ pada kata Lutfi. Fonem konsonan /f/ merupakan konsonan geseran (frikatif) labiodentals. Fonem /f/ adalah fonem konsonan yang terjadi bila artikulator aktifnya adalah bibir bawah dan artikulator pasifnya adalah gigi atas. Fonem /p/ adalah konsonan keras tidak bersuara. Fonem konsonan /p/ merupakan konsonan hambat letup bilabial. Fonem /p/ adalah fonem konsonan yang terjadi bila penghambat artikulator aktifnya bibir bawah dan artikulator pasifnya bibir atas. Fonem /p/ adalah konsonan keras tidak bersuara. Dari keterangan di atas kedua pelafalan konsonan tersebut memiliki perbedaan, yaitu pelafalan fonem /f/ yang seharusnya dilafalkan dengan artikulator pasifnya adalah gigi atas tetapi penutur tidak dapat melafalkan fonem /f/ dan melafalkannya dengan fonem /p/. Hal ini dikarenakan penutur memudahkan pelafalannya yang dipengaruhi oleh faktor internal, keterlambatan bicara.

\section{Pemerolehan Sintaksis b. Frasa Nominal}

Pemerolehan sintaksis yang dimiliki MR cenderung dalam bentuk frasa. Data berikut adalah hasil pemerolehan sintaksis MR pada kelas frasa nominal.

MR: Atuh, uwa, iga epat, lima , enam, tujuh, apan, iyan, uyuh

MR: Ana mama

MR: Ini epong

MR: Hawo

MR: Ini

(Data No.25/PS/28/05/2018)

\section{Ujaran: Ini epong}

Arti: ini telpon

Pengujar: GR (Guru), MR (Subjek Penelitian)

Konteks :MR sedang bermain telpon-telponan. MR menunjukkan kepada guru bahwa ia sedang menelpon.

Berdasarkan data di atas ujaran ini opok, ini gigi obot merupakan frasa nominal. Frasa nominal adalah Frasa yang memiliki distribusi yang sama dengan kata nominal. Frasa nomina harus diikuti oleh kata nomina. Kata nomina yang mengikuti inilah yang akan membentuk frasa nomina. Pada frasa ini opok mempunyai distribusi yang sama dengan kata opok (robot). Kata opok (robot) termasuk golongan kata nominal, karena itu frasa ini opok (robot) termasuk frasa nominal. Jika kata ini tidak dituliskan maka tidak akan merubah makna dari ujaran itu sendiri. Selanjutnya pada frasa ini epong (ini telpon) mempunyai distribusi yang sama dengan kata telpon. Kata epong (telpon) termasuk frasa golongan nominal, karena itu frasa ini epong (ini telpon) termasuk frasa nominal. Jika kata ini tidak dituliskan maka tidak akan merubah makna dari ujaran itu sendiri. 


\section{KESIMPULAN}

Beradasarkan hasil analisis data yang dilakukan oleh peneliti mengenai pemerolehan bahasa anak ADHD dengan keterlambatan bicara, maka dapat dikatakan bahwa peneliti mengumpulkan data berupa ujaran yang diucapkan dari alat ucap subjek penelitian yang menjadi data penelitian ini. Pemerolehan bahasa pada subjek penelitian yang menjadi data peneliti adalah pemerolehan fonologi. Hasil analisis data mengenai pemerolehan fonologi antara lain MR memiliki pemorolehan fonologi jenis konsonan hambat letup bilabial /b/ dan /p/, hambat letup apiko-dental /t/ awal dan /d/ akhir, hambat letup apiko-palatal /t/ tengah dan /d/ awal, hambat letup medio-palatal /c/ dan $/ \mathrm{j} /$, hambat letup dorso-velar $/ \mathrm{k} / \mathrm{dan}$ $/ \mathrm{g} /$, nasal bilabial $/ \mathrm{m} /$, nasal apikoalveolar /n/, nasal medio-palatal / $\mathrm{n} /$, nasal dorso-velar $/ \eta /$, sampingan $/ 1 /$, geseran labio-dental /f/, geseran laminoalveolar /s/ dan /z/, laringal /h/, getar /r/ dan semivokal bilabial dan labio-dental /w/, medio-palatal /y/.

Hasil analisis data mengenai kesalahan fonologi yaitu, dapat disimpulkan bahwa kesalahan fonologi yang terjadi pada anak ADHD dengan keterlambatan bicara adalah dari faktor internal. Kesalahan pelafalan berupa kesalahan pelafalan fonem konsonan atau perubahan fonem konsonan antara lain perubahan fonem konsonan /f/, /s/, $/ \mathrm{b} /, \quad / \mathrm{k} /, \quad / \mathrm{m} /$ dilafalkan /p/, fonem konsonan /l/ dilafalkan /w/, fonem konsonan $/ \mathrm{h} /$, fonem konsonan /z/ dilafalkan $/ \mathrm{m} /$, fonem konsonan $/ \mathrm{r} /$ dilafalkan $/ \mathrm{h} /$, fonem konsonan /l/ dilafalkan /d/, fonem konsonan /g/ dilafalkan /j/, fonem konsonan /r/, /h/, /l/, dilafalkan /y/, fonem konsonan /g/ dilafalkan $/ \mathrm{n} /$, fonem konsonan $/ \mathrm{r} /$ dilafalkan /b/, fonem konsonan /s/ dilafalkan /c/, fonem konsonan /t/ dilafalkan $/ \mathrm{k} /$. Kesalahan penghilangan fonem konsonan antara lain konsonan $/ \mathrm{l} /, / \mathrm{p} /, / \mathrm{b} /, / \mathrm{d} /, / \mathrm{t} /, / \mathrm{j} /, / \mathrm{\eta} /, / \mathrm{k} /, / \mathrm{m} /, \mathrm{r}, / \mathrm{n} /$, /h/ dan kesalahan penambahan fonem konsonan $/ \mathrm{h} /$. Hasil analisis data ketiga yang dilakukan peneliti mengenai pemerolehan sintaksis. Pemerolehan sintaksis yang sudah dimiliki subjek antara lain frasa nominal, frasa verbal, frasa depan, dan frasa bilangan serta kalimat berita dan kalimat suruh.

\section{DAFTAR PUSTAKA}

Bila, S. (2017, September 15). Ternyata Keterlambatan Bicara Bisa Jadi Awal Dari Sejumlah Gangguan Serius yang Dialami Anak. Retrieved Mei 23, 2018, from Sayangi Anak: www.sayangianak.com

Buitelaar, A. P. (2010). ADHD (Attention Deficit Hyperactivity Disorder). Jakarta: Prenamedia Group.

Candrasari, L. A. (2014). Pemerolehan Bahasa anak Usia \#-4 tahun di Desa Gombong Kecamatan Belik Kabupaten Pemalang : Kajian Psikolinguistik.

Chaer, A. (2013). Fonologi : Bahasa Indonesia Jakarta. Jakarta: PT. Rineka

Cipta. (2015). Psikolinguistik Kajian Teoritik. Jakarta: PT Rineka Cipta.

Dardjowidjojo, S. (2003). Psikolinguistik: Pengantar Pemahaman Bahasa Indonesia. Jakarta: Yayasan Pustaka Obor Indonesia.

FIP-UPI, T. P. (2007). Ilmu dan Aplikasi Pendidikan. Jakarta: IMTIMA.

Gunarsa, S. D. (2008). Dasar dan Teori Perkembangan Anak. Jakarta: PT. BPK Gunung Mulia.

Herlina. (2016). Pemerolehan Fonologi Pada Anak Usia 2 Tahun 2 Bulan (Studi Kualitatif pemerolehan Fonologi Pada Aisyah) .

Jahja, Y. (2011). Psikologi Perkembangan.

Jakarta: Prenadamedia.

Kadir, T. H. (2016). Pengembangan Proses Pembelajaran Teori 
Behaviorisitk Untuk Anak Berkebutuhan Khusus. 109.

Mahsun, M. (2012). Metode Penelitian Bahasa, Tahapan, Strategi, Metode, dan Tekniknya. Jakarta: RajaGrafindo.

Mar'at, S. (2011). Psikolinguistik Suatu Pengantar. Bandung: PT Revika Aditama.

Marsono. (2013). Fonetik. Yogyakarta: Gajah Mada University Press.

Moleong, L. J. (2015). Metodelogi Penelitian Kualitatif. Bandung: PT Remaja Rosdakarya.

Muslich, M. (2008). Fonologi Bahasa Indonesia. Jakarta: PT Bumi Aksara.

Pemerolehan Bahasa Pertama Anak Usia 0-3 Tahun Dalam Bahasa Seharihari (Tinjauan Psikolinguistik). (2016). Yosep Trinowismanto , 3370.

Putri, N. D. (2015). Analisis Pemerolehan Fonologi Pada Penderita Down Syndrom .

Ramlan, P. D. (2005). Sintaksis. Yogyakarta: C.V. Karyono.

Setyawati, N. (2010). Analisis Kesalahan Berbahasa Indonesia Teori dan Praktis. Surakarta: Yuma Pustaka.

Sugiyono, P. D. (2014). Metode Penelitian Kuantitatif dan Kualitatif dan $R \& D$. Bandung: Alfabeta.

Tiel, J. M. (2007). Anakku Terlambat Bicara. Jakarta: Prenamedia Group.

Wardiani, A. Y. (2016). Pemerolehan Bahasa Penderita Tunagrahita Pada Siswa SD Kelas 1 C di SLB Negeri Banjarnegara Kecamatan Madukara Kabupaten Banjarnergara tahun 2016. 